\title{
NEWS FOR THE MEMBERS
}

THE ORGANIZATION FOR THE PROMOTION OF SOCIAL SCIENCES IN THE MIDDLE EAST was established at the conclusion of a conference on the State of the Social Sciences in the Middle East held in Alexandria in July 1974. The conference participants elected a Secretary-General (Laila El-Hamamsy), an Executive Committee (Abdel Ghaffar Ahmed, Jamshid Behnam, Fuad I. Khuri, Serif Mardin, Farouk Murad and Abdelkader Zghal) and country Liaison Officers (Ahmed Abou Zeid-Egypt, Abdel Ghaffar Ahmed-Sudan, Fakher Akil-Syria, Maliha Al-Kassir-Iraq, Mohamed Barhoum-Jordan, Mohamed El-Rumaihi-Kuwait, Joseph FarisLebanon, Cigdem Kagitcibasi-Turkey, Farouk Murad-Saudi Arabia, Afshar N. Naderi-Iran and Hachemi Karoui-Tunisia) to carry out the functions and activities of the organization. The social sciences referred to here include sociology, anthropology, social psychology, and political science. The Organization is to operate for an interim period of two years. Its main functions are to promote communication, to develop collaborative programs among the social scientists of the region, and to lay the groundwork for the establishment of a formal Middle East social science association. The activities envisaged include the publication of a newsletter (Number 1 appeared in April 1975), the compilation of a directory of social scientists, the promotion of direct communication through workshops and seminars, and the drafting of a constitution for the proposed association for presentation at a conference to be held in the summer of 1976. The conference would serve not only as a constituent assembly but also as a professional social science convention at which papers would be read and discussed. For further information, write Laila Shukry El-Hamamsy, Director, Social Research Center, The American University in Cairo, 113 Sharia Kasr el-Aini, Cairo, Egypt.

THE TURKISH STUDIES ASSOCIATION would like to invite membership of all those interested in its work. Now in its fifth year, the TSA is a private, non-profit, non-political organization of scholars and other persons interested in Turkish and ottoman Studies. Its objectives are (a) to promote high standards of scholarship and instruction, (b) to facilitate communication among its members through meetings and written exchanges of information, and (c) to promote international scholarly cooperation among persons and organizations concerned with Turkish and ottoman Studies. Among its activities are a Newsletter three times yearly, which includes short articles on recent developments in areas such as education, migration and folklore; reports of meetings and conferences; publications and research in progress by the members; and which will in the future expand to add book reviews, research notes, and other items of general interest. The annual meeting is held each November in conjunction with the annual meeting of the Middle East Studies Association. Dues for Regular members (scholars and teachers) and for Associate members (others interested in furthering the work of the Association) are $\$ 5.00$ per year, and for students $\$ 2.00$. For further information, write the secretary, Professor Walter F. Weiker, Department of Political Science, Rutgers University, Newark, New Jersey 07102 . Samples of recent Newsletters may be obtained from the Editor, Professor Ilhan Basgdz, 143 Goodbody Ha11, Indiana University, Bloomington, Indiana 47401 .

A preliminary catalogue of the holdings of the ARCHIVE OF TURKISH ORAL NARRATIVE is now available and will be sent free to MESA members who request it. For further information, write Professor Warren S. Walker, Archive of Turkish Oral Narrative, Texas Tech University, P.o. Box 4185, Lubbock, Texas 79409. 
THE CENTER FOR MIDDLE EASTERN STUDIES, UNIVERSITY OF TEXAS AT AUSTIN, is sponsoring the publication of a series of short softbound books to supplement the established hardbound series. It invites the submission of short monographs (under 200 pages) on any area of Middle Eastern studies for consideration in the series. Inquiries and manuscripts should be addressed to the Editorial Board, Center for Middle Eastern Studies, University of Texas at Austin, Austin, Texas 78712 .

THE UNIVERSITY OF UTAH MARRIOTT LIBRARY has received as a gift a $1,435-i t e m$ collection of manuscripts, papyri fragments and scrolls. The gift was made by Dr. Aziz S. Atiya, Distinguished professor of History at the University of Utah. The donated items include four papyrus fragments of ancient scrolls, 180 ragpaper and old paper scrolls from the loth century, 1,185 manuscript folios from the lith to the 19 th century, and 66 tracts and treatises in Arabic manuscript from the 12 th to the 19 th century.

THE PRIVATE INFORMATION CENTER ON EASTERN ARABIA is a non-profit research center founded in 1970 by Mr. Marc Van Daele. The Head Office of the Center is in vilvoorde, Belgium, and includes a specialized library of 3500 documents on Bahrain, Qatar, Oman, and the United Arab Emirates. Some of its activities are the publication of facts sheets on Eastern Arabia that cover such subjects as education, genealogies of ruling families, post office, history, hea 1 th, government's lists, budget, diplomatic relations, fishing, external trade, imports and investments regulations, banking, industries, petroleum, trade with EEC countries, civil aviation, etc. It also publishes monthly bibliographies of new acquisitions. For further information, write Mr. Marc Van Daele, Director, private Information Center on Eastern Arabia, Heldenplein 12, 1800 Vilvoorde, Belgium.

Muhammad Umar Memon and David M. Knipe of the Department of South Asian Studies, University of Wisconsin, Madison, have recently produced a 30-minute color videocassette ISLAM IN SOUTH ASIA, which forms part of a 15-cassette presentation EXPLORING THE RELIGIONS OF SOUTH ASIA. Islam in South Asia deals with the specific contribution and expressions of Islam in the Indo-Pakistani sub-continent, including such topics as the traditions of Speculative and Popular Sufism, folk Islam, Urdu literature, and architecture. It also provides a general introduction to the Islamic faith and practice. The videocassette is being sold at cost price of $\$ 45.00$. For purchase, preview copy on approval, or for further information, write to Professor David M. Knipe, University of Wisconsin, Department of South Asian Studies, 1220 Linden Drive, Madison, Wisconsin 53706. 